SJ Quinney College of Law, University of Utah Utah Law Digital Commons

Utah Law Faculty Scholarship

Utah Law Scholarship

$5-2016$

\title{
Title IX: An Incomplete Effort to Achieve Equality in Sports
}

Leslie Francis

S.J. Quinney College of Law, University of Utah, leslie.francis@law.utah.edu

Follow this and additional works at: https://dc.law.utah.edu/scholarship

\section{Recommended Citation}

Francis, Leslie, "Title IX: An Incomplete Effort to Achieve Equality in Sports" (2016). Utah Law Faculty Scholarship. 92. https://dc.law.utah.edu/scholarship/92

This Article is brought to you for free and open access by the Utah Law Scholarship at Utah Law Digital Commons. It has been accepted for inclusion in Utah Law Faculty Scholarship by an authorized administrator of Utah Law Digital Commons. For more information, please contact valeri.craigle@law.utah.edu. 
Title IX: An Incomplete Effort to Achieve Equality in Sports

Title IX, the part of the Education Amendments of 1972 that prohibits discrimination based on sex in educational programs receiving federal financial assistance, has brought vast increases in the participation of women in sports across educational institutions in the United States. Despite this impressive achievement, Title IX has also been the target of criticism from both its supporters and its critics. Supporters argue that the great strides in participation brought by Title IX have not brought deserved fan support, spectators, revenue, or respect for women in sports, with the rare exceptions of individual stars such as Mia Hamm in soccer or Serena Williams in tennis, or teams such as the University of Connecticut women's basketball team. Critics argue that Title IX's gains, such as they are, are accompanied by significant losses of participation for men in sports: the decline of men's wrestling or gymnastics programs or the failure to implement men's soccer at many universities.

This article seeks to move beyond equality of participation, especially when it is seen as similarity in numbers, as a conceptualization of equality for women in sports in educational institutions. Moving beyond participation in equal numbers, I argue, requires developing an understanding of both the purpose of sports in educational institutions and the meaning of equality as inclusion. Two concrete conclusions about Title IX follow: (1) football, a sport played primarily by men and developed to showcase characteristics of male bodies, should be treated separately for purposes of analyzing whether equality has been achieved; and, (2) where possible sporting events should be restructured to include both male and female competitions as part of the same event. Robert Simon has been a powerful intellectual force in the philosophy of sport for nearly half a century. I hope this contribution reflects the spirit of his concern for serious thinking about the purpose of sports in contemporary society.

\section{Title IX and its Achievements}

Title IX, enacted in 1972, prohibits discrimination on the basis of sex in any federally funded educational program or activity. ${ }^{1}$ Early in the history of Title IX, the United States Supreme Court held that Title IX coverage applied only to specific programs receiving federal financial assistance such as financial aid programs. ${ }^{2}$ Four years later, Congress restored institution-wide coverage with the Civil Rights Restoration Act of 1987.3

120 U.S.C. $§ 1681(\mathrm{a})(2015)$.

2 Grove City College v. Bell, 465 U.S. 555 (1984).

3 Civil Rights Restoration Act of 1987, Pub. L. 100-259, 102 Stat. 28 § 3(a)(2)(A). 
The Title IX regulations contain specific provisions relevant to athletics. These regulations contain a general non-discrimination provision ${ }^{4}$ followed by provisions allowing separate teams and standards for determining equality of opportunity.

Separate teams are allowed in sports where selection is based on competitive skill or the activity involves contact. ${ }^{5}$ This provision poses a problem if institutions offer a team for one sex but not for the other. In such cases, the regulation provides that members of the other sex must be allowed to try out for the existing team if opportunities for that sex have historically been limited. This requirement does not apply to contact sports, including boxing, wrestling, rugby, ice hockey, football, basketball, or other sports in which the purpose or activity involves bodily contact.

In practice, very few litigated cases have involved efforts by one sex to try out for teams offered only for the other sex. Field hockey is typically a women's sport; John Williams' effort to try out for his high school's girls' field hockey team was rebuffed by a school district rule that boys could not play on girls' field hockey teams. ${ }^{6}$ His parents sued on his behalf, claiming a violation of Title IX. In reply, the school district argued that field hockey is a contact sport and that tryouts for boys would only be required when athletic opportunities for boys had previously be limited. The appellate court held that the district court had erroneously granted summary judgment for Williams on whether field hockey is a contact sport; the school district had submitted affidavits that put into question whether bodily contact was a major activity of the sport in light of how the sport is actually played. On the issue of whether athletic opportunities for boys had previously been limited, the appellate court also rejected the district court's reasoning. Because district high schools operated 10 girls', 10 boys', and 2 coed teams, and permitted girls to try out for all 22 teams but boys to try out for only 12 , the district court had reasoned that boys' opportunities had been limited. The appellate court found this argument "flawed," because athletic opportunities must be "real opportunities, not illusory ones."7 Otherwise, schools could meet Title IX's mandate of equal opportunity merely by opening tryouts to women. The appellate court also rejected Williams' argument that the historical limitation test should apply only to the sport in question. If so, the court said, then all single-sex, non-contact sports would be by definition sports that had historically limited opportunities for the other sex. The appellate court also scrutinized the regulatory language, concluding that it referred to overall athletic opportunities for the excluded sex, not opportunities in the specific sport at issue.

In a high-profile case of a woman trying out for a men's sport, Duke University permitted Heather Sue Mercer to try out for their men's football team as a walk on place kicker. Although she did not make the team initially, she attended practices, participated in conditioning drills, and served as a team manager. The team's

434 C.F.R. $\S 106.41$ (2015).

534 C.F.R. § 106.41(b) (2015).

${ }^{6}$ Williams v. School District of Bethlehem, Pa. 998 F.2d 168 (3d Cir. 1993).

7998 F.2d at 175 . 
seniors selected her to play in the spring Blue/White scrimmage game, she kicked the winning field goal, and the coach announced that she was a member of the team. Not surprisingly, widespread media attention ensued; the coach became concerned about negative implications for the team, refused to let her participate with the team, made many negative comments, and eventually cut her from the team. Her subsequent suit alleging Title IX violations garnered an initial ruling that once Duke had permitted her to try out for the team, it could not invoke the contact sports exception with respect to non-discrimination in her subsequent treatment. ${ }^{8}$ Eventually, Mercer won a $\$ 1$ compensatory damages award, and a $\$ 2$ million punitive damages award from a jury later vacated by the appellate court for reasons not relevant to the questions of non-discrimination that are the subject of this article, ${ }^{9}$ and $\$ 350,000$ in attorney's fees. ${ }^{10}$

The regulatory standards for assessing equality of opportunity list the following factors: whether the selection of sports and competition levels "effectively accommodate" interests and abilities of both sexes, equipment and supplies, scheduling of games and practices, travel and per diem, coaching and academic tutoring, assignment and compensation of coaches and tutors, locker rooms and competitive and practice facilities, medical and training facilities and services, housing and dining facilities and services, and publicity. ${ }^{11}$ This list is not inclusive; other factors may come into play in particular cases. In addition, the regulations specifically provide that unequal aggregate expenditures for separate teams are not noncompliance, but failures to provide for needed expenditures of a team of one sex may be considered in assessing equality of opportunity.

After the Title IX regulations became effective, the Department of Health, Education, and Welfare received many complaints about violations. Investigating the complaints revealed the need for further policy guidance, which the Department issued in 1979.12 The Guidance provides that compliance in financial assistance should be assessed by substantial proportionality with the number of male and female participants in an institution's athletic program. This is a quantitative comparison of the total amount of aid divided by the numbers of participants. Disparities may be justified by factors such as the ratio of instate to out-of-state athletes, so long as there is not discrimination in the availability of out of state scholarships. Compliance in other factors listed in the regulation should be based on "equivalent treatment, benefits, and opportunities" for male and female athletes. In addition to the factors enumerated in the regulation, other factors such as recruitment and other support services may also be considered. The Guidance

8 Mercer v. Duke University, 190 F.3d 643 (4th Cir. 1999).

${ }^{9}$ Mercer v. Duke University, 50 Fed. Appx. 643 (4th Cir. 2001).

${ }_{10}$ Mercer v. Duke University, 401 F.3d 199 (4th Cir. 2005).

1134 C.F.R. § 106.41(c)(1)-(10) (2015)

12 Department of Health, Education and Welfare. A Policy Interpretation: Title IX and Intercollegiate Athletics. 44(239) Fed. Reg. 71413, http://www2.ed.gov/about/offices/list/ocr/docs/t9interp.html (Dec. 11, 1979). 
provides that the benefits, opportunities and treatment of both sexes must be "equivalent, that is, equal or equal in effect." Nondiscriminatory differences among unique aspects of sports, such as differences in costs or rates of wear of equipment, may justify non-equivalence.

Finally, overall compliance in meeting the interests and abilities of male and female students is equally effective accommodation. This requires determining the athletic interests and abilities of students through non-discriminatory methods that are responsive to expressed interests of capable students who are members of the underrepresented sex. It also requires appropriate selection of sports-but not integration of teams or exactly the same choices of sports for men and women. A further requirement is levels of competition that equally reflect the abilities of men and women. This may be assessed by intercollegiate participation opportunities for men and women that are proportional to enrollment, by a continuing practice of program expansion against a history of underrepresentation, or by a demonstration that the interests and abilities of the members of the underrepresented sex have been "fully and effectively accommodated" by the program.

The Guidance thus develops three tests, applied to different aspects of nondiscrimination in athletics:

1. A test of quantitative sameness in the sense of equal numbers, numbers proportional to overall numbers of participants. This test is applied to participation rates and scholarships.

2. A test of equivalence in effect in the sense of whether women and men are similarly able to play their sport. This test is applied to factors that reasonably may differ by sports, such as equipment, transportation costs, or crowd management costs.

3. A test of full and effective accommodation in the sense of whether sports are offered kinds and levels of opportunity needed to provide opportunities that suit the interests of the existing or anticipated student body. This test is applied to sport selection and competition levels but does not require integration of sports or selection of exactly the same sports for men and women.

In a symposium on equality for women in sports published in 1993 in this journal, I characterized these tests as an "uneasy compromise between equal levels of participation and the historical differences between men's and women's sports." ${ }^{13}$ I now would add the dimension that it also reflects deep tensions in the understanding of equality itself. Equality understood as sameness - as in the same numbers test-is very different from equality understood as equivalent benefit-as in the equivalent ability to play-and different still from full and effective opportunities for the student body.

13 Leslie P. Francis, Title IX: Equality for Women's Sports? Journal of the Philosophy of Sport 1993-94: 32-47, at 37 (1993). 
Not surprisingly, interpretation of these standards has proved daunting for courts. These difficulties are complicated by the fact that Title IX is not the only law in play in most of the anti-discrimination litigation: against state colleges or universities, violation of the Equal Protection Clause of the U.S. Constitution is often in the mix; Title VII of the Civil Rights Act may be invoked by employees such as coaches alleging employment discrimination; and a variety of state anti-discrimination laws are often involved as well. Two relatively recent cases are especially helpful illustrations of the different tests in practice.

In the first case, women athletes at LSU brought suit challenging the university's failure to field women's varsity soccer and fast-pitch softball teams. The litigation also involved allegations of unequal treatment in benefits, for example differences between coaches' salaries in men's and women's basketball. The court denied the women athletes standing on the unequal treatment allegations, because they had not sought to participate in the sports in question and so were not directly injured by the differences in coaching. Their challenge was to LSU's failure to effectively accommodate them by fielding teams in their chosen sports. LSU's response-that they had met the effective accommodation standard-was met with clear scorn by the court. Notably, in its analysis the court carefully distinguished the three different ideas of equality above, applying the failure to provide equally effective accommodations to student body interests as the legal standard relevant to the LSU athletes' Title IX claims. LSU argued first that there was not sufficient interest and ability on campus to justify adoption of women's soccer or softball, but their suggested standard was that "an institution with no coach, no facilities, no team, no scholarships, and no recruiting in a given sport must have on campus enough national-caliber athletes to field a competitive varsity team" in that sport. ${ }^{14}$ In the court's judgment, this was clearly a risible standard that no plaintiffs could ever meet. The court also argued that proportionality could be considered in judging effective accommodation, because "of course fewer women participate in sports" when there is a climate of discrimination against them. Finally, the court determined that the Guidance requires the university to fully investigate whether the selection and level of competition effectively accommodates the interests and abilities of both sexes, which LSU had not done. ${ }^{15}$ This case illustrates the difference between numerical equality and effective accommodation, and emphasizes the importance of full assessment of the latter.

In the second case, Mamaroneck school district scheduled boy's soccer in the fall and girl's soccer in the spring. This scheduling precluded girls from the opportunity to participate in regional and state championships that were held in the fall. It also

\footnotetext{
${ }^{14}$ Pederson v. Louisiana State University, 213 F.3d 858, 878 (5 ${ }^{\text {th }}$ Cir. 2000).

${ }^{15}$ LSU now offers women's soccer, http://www.lsusports.net/SportSelect.dbml?SPID=2168, and softball, http://www.lsusports.net/SportSelect.dbml?\&DB_OEM_ID=5200\&SPID=2174\&SPSI $\mathrm{D}=27870$.
} 
created scheduling conflicts with club teams and Olympic development teams. ${ }^{16}$ The school district's submissions included evidence from other girls that they would prefer soccer to remain in the spring so they could play other sports (e.g. field hockey) in the fall. The district court held that the scheduling disparity by itself was unequal and thus a violation of Title IX. On appeal, the Second Circuit distinguished the three tests given above and applied the effective accommodation test to athletic participation opportunities. In so doing, it disagreed with the district court's test of whether scheduling of boys' and girls' soccer was equal in the sense of scheduled at the same time of the year, which the sports clearly were not. Instead, it asked whether this difference was "substantial enough" to deny equal athletic opportunity not offset by comparable advantages in other aspects of the athletic program. ${ }^{17}$ The disparity was clear and had a negative impact on girls; the school district had not identified any areas of comparably better treatment for girls or any examples of boys' sports similarly disadvantaged. And the disparity was substantial because it placed a competitive ceiling on a girls' sport that was not encountered by the equivalent boys' sport. With regard to the school district's argument that it had effectively accommodated the interests of girls who wished to participate in sports, the court, noting that the affidavits were highly selective and hence potentially not representative, also pointed out that effective accommodation required consideration of the level and quality of competition offered. The appellate court remanded the case to the district court to allow the districts to decide whether they should alternate boys' and girls' soccer in the fall or offer both in the fall.18

Courts thus treat "effective accommodation" as a different requirement than sameness or even similarity of treatment. I will have more to say below about the Guidance's understanding of "full and effective accommodation" as not requiring integration of sports-and how the Guidance thus leaves undisturbed how sports actually are played. In light of understandings of accommodation that have been developed in other areas of anti-discrimination law such as religious accommodation or accommodation of disability, this approach is questionable.

\section{Simon's view: Equality understood in terms of the purpose of sports.}

In the symposium published in this journal in 1993 and referred to above, I argued that equality for women in collegiate athletics should be seen as a problem of how to achieve equality within a morally flawed social practice. Justifications for the emphasis on revenue-producing sports, I argued, were tenuous at best. In this context, equality for women in sports required consideration of a wide range of

16 McCormick ex rel. McCormick v. School District of Mamaroneck, 370 F.2d 275, 281 (2d Cir. 2004).

17370 F.2d at 293.

18 The schools now offer both sports in the fall, Mamoronek Athletics, http://www.mamaroneckathletics.org/. 
possible steps to be taken in response to discrimination. ${ }^{19}$ But these steps should be considered in a context in which an historically disadvantaged group-women in athletics - sought fuller participation in an activity that was itself socially problematic. Here, I considered in particular whether risks to the individuals participating, costs in comparison to overall benefits, or overall undesirable consequences vitiated the case for further inclusionary steps. I concluded that risks to participants did not justify excluding women but not men from contact sports, just as they do not justify excluding women but not men from clinical trials. Evidence questioning the benefits of participation in varsity sports undercuts the case for increasing opportunities for women based on benefits to them, but it remains unjustifiable to provide what benefits there might be disproportionately to men. With respect to the overall undesirable consequences of the activity, I considered whether society was on the whole attempting to discourage the activity and concluded that if it was not, it would be worse from the point of view of justice to continue the activity without women than to make efforts to try to include them. At the end of the article, I suggested some ways of moving beyond Title IX: that universities might do more to encourage women to participate in non-varsity skills training and sports activities, that universities might expand participation in and support for intramural sports programs, that universities might reconsider what are sports in the first place, and that universities might consider fielding coeducational

${ }^{19}$ In the article, I used the term "affirmative action" to refer to such positive steps. Francis, p. 38. Despite all the opprobrium that has been heaped on the term as requiring unjustifiably exclusionary quotas, "reverse discrimination," or rejection of appropriate qualifications, the need for positive steps was its original meaning and should not be forgotten. As originally conceived, affirmative action did not require injustice; it required consideration of what practical steps could be taken to address existing discrimination. See, e.g., Office of Federal Contract Compliance Programs, Executive Order 11246, EEO Affirmative Action Guidelines for Federal Contractors Regarding Race, Color, Gender, Religion, and National Origin, http://www.dol.gov/ofccp/regs/compliance/fs11246.htm (Sept. 24, 1965). The Guidelines provide:

"Each Government contractor with 50 or more employees and $\$ 50,000$ or more in government contracts is required to develop a written affirmative action program (AAP) for each of its establishments.

A written affirmative action program helps the contractor identify and analyze potential problems in the participation and utilization of women and minorities in the contractor's workforce.

If there are problems, the contractor will specify in its AAP the specific procedures it will follow and the good faith efforts it will make to provide equal employment opportunity.

Expanded efforts in outreach, recruitment, training and other areas are some of the affirmative steps contractors can take to help members of the protected groups compete for jobs on equal footing with other applicants and employees." 
varsity teams. I continue to support these ideas and will have more to say about the last below.

In the same symposium, Simon identified and examined some of the major issues arising as gender equality in athletics. ${ }^{20}$ His argument began by setting out some of the benefits of sport: healthy exercise, the opportunity to learn to compete, fame and fortune, other opportunities, and the constitutive benefits of the practice of a particular sport in the sense of experiencing the goods that make up the sport. Simon also cast a critical eye on my skepticism about intercollegiate athletics, noting fairly that only a fraction of colleges and universities compete in Division I, the division against which many of the criticisms are most reasonably directed. Simon also developed an account of the educational purposes of sports, such as commitment to effective performance and tests of excellence.

Against this background, Simon presented an illuminating account of different conceptions of gender equity. One account, put forth by the Gender Equity Task Force of the NCAA, and somewhat Rawlsian in flavor, is whether participants in both the men's and women's programs would accept as fair and equitable the overall program of the other gender. This account, Simon argues, is beset by difficulties including the potential for disagreement among men and among women about what fairness requires and because of a failure to specify what is really meant by taking the perspective of the other. So, Simon suggests, we should move ahead under the overall rubric that an athletic program is gender equitable if it "makes no unjustified distinctions between the genders." 21

Simon then applies this rubric to the Guidance three-part test outlined above. He admires the Guidance for taking equality to be the presumption with departures requiring justification. He then raises questions about the proportionality and effective accommodation aspects of the test. About proportionality, he notes that at the time significant disparities in participation remained at the high school level, perhaps suggesting difference in levels of interest. He questions whether varsity sports at the university level are the appropriate place to cultivate such interests, even if their absence is arguably unjust. He also notes the unintended, but likely unjust consequence that proportionality may be achieved as much by cutting men's sports and disadvantaging men as by increasing participation in women's sports.

About full and effective accommodation, Simon questions the extent of what it might require. Here, he is particularly critical of my use of the argument from affirmative action that past injustice might warrant positive steps to improve the position of women. One concern he raises is that those who would stand to benefit from affirmative steps may not be the individuals who were victimized by prior injustice. Another concern is that it may be difficult to decide which gender has been

20 Robert L. Simon, Gender Equity and Inequity in Athletics. Journal of the Philosophy of Sport 1993-1994: 6-22 (1993).

21 Simon, p. 10. 
underrepresented in light of actual interests in participating; the reply, which he acknowledges, is that actual interests may themselves reflect underlying injustices that contribute to the formation of interests. (If women are discouraged from participating in athletics, teased about skills they do develop, or lack competitive opportunities altogether, it would be reasonable to expect that they might not develop interests.) Nonetheless, he finds the idea of "full and effective" accommodation problematic, especially if it is to be weighed against other considerations that might be highly controversial, such as balancing opportunities for men against opportunities for women. He concludes this section by stating that no a priori solution is possible and that the understanding of effective accommodation is "probably best left to emerge from case law and consideration of actual and hypothetical examples in moral discourse."22

In the final section of his contribution to the symposium, Simon considers whether the problem is the existing framework of intercollegiate sport. Here, he suggests that women are not treated unfairly by the dominant position occupied by football on many campuses. If women are not effectively accommodated, however, issues of redistribution are likely to be complex and divisive. Solutions such as eliminating separate teams in favor of single coed teams are also problematic if they involve cutting support. There may be losses for women if women must compete directly against men. It may be possible to educate spectators to appreciate the nuances of women's sports. Finally, Simon hypothesizes that perhaps equity would best be addressed within the context of less commercialized models of athletics such as represented by Division III institutions in college sports in the United States.

These are all important points, undergirded by Simon's deep appreciation of the goods of sports and the varied landscape of how these goods are realized in the U.S. today. However, I was unsatisfied then and remain unsatisfied today by Simon's picture of what at least some proponents of equality as effective access understand this to mean. At the core of my dissatisfaction is the need for a more developed understanding of how to theorize achieving justice under conditions of injustice. Simon does not theorize in this way, as his view that effective accommodation is best left to case law and consideration of examples illustrates.

\section{The Changing Landscape of Equality in College and University Sports}

Much has transpired in the intervening nearly 25 years since this journal's earlier symposium on equality in college and university sports was published-and even more so in the over 40 years since the advent of Title IX. Perhaps most importantly at the theoretical level, non-ideal theory approaches to ethics have grown more prominent and far more sophisticated. A substantial literature has developed in moral philosophy about what justice might require in a variety of circumstances of

22 Simon, p. 17. 
injustice. ${ }^{23}$ This literature, however, has remained largely unexplored among philosophers of sport.

For my purposes here, the most important issues in non-ideal theory are how it directs attention to the implications of existing social circumstances for what justice requires. Context matters, raising questions such as how can progress best be made towards justice, what injustices take precedence to address, what strategies are likely to create new roadblocks to overcoming injustice, or what are the obligations of individuals or institutions when others continue to behave unjustly. This last question is particularly pressing in competitive contexts or contexts of scarcity: individuals who take on greater shares in achieving justice while others do not may find themselves or those who depend on them at increasingly unfair disadvantages. ${ }^{24}$

Another theoretical development of relevance to my discussion here is the development of the jurisprudence of accommodations in civil rights law. The Rehabilitation Act, enacted the year after Title IX, prohibits discrimination on the basis of disability in federally funded programs. Both the Rehab Act and its complement the Americans with Disabilities Act define discrimination as the failure to make reasonable accommodations or modifications for otherwise qualified individuals unless such changes would be an undue hardship or expose people to a direct threat. In an important early decision applying the Rehab Act, Alexander $v$. Choate, the United States Supreme Court explained that equal opportunity requires providing qualified individuals with "meaningful access" to federally funded programs. $^{25}$ My suggestion here is that the jurisprudence of meaningful access is helpful in fleshing out what the third standard for Title IX equality might mean: the test of full and effective accommodation in the sense of whether sports are offered kinds and levels of opportunity needed to provide opportunities that suit the interests of the existing or anticipated student body. Access is not meaningful if

${ }^{23}$ E.g. Laura Valentini, Ideal vs. Non-ideal Theory: A Conceptual Map. Philosophy Compass 7(9): 654-664 (2012); Zofia Stemplowska, What's Ideal About Ideal Theory? Social Theory and Practice 34(3): 319-340.

${ }^{24}$ E.g., David Miller, Taking up the Slack? Responsibility and Justice in Situations of Partial Compliance, in Zofia Stemplowska and Carl Knight, eds. Responsibility and Distributive Justice (Oxford: Oxford University Press, 2011), pp. 230-245; G.A. Cohen, If You're an Egalitarian, How Come You're So Rich? Cambridge, Mass.: Harvard University Press 2000.

25 Alexander v. Choate, 469 U.S. 287 (1985). The plaintiffs in the case were Tennessee Medicaid recipients challenging the state's limitation of hospital days per year covered under the program. Although the Court held that the plaintiffs had not shown that they lacked meaningful access to hospital services, its adoption of the meaningful access standard has proved critical for subsequent plaintiffs challenging disability discrimination, see Anita Silvers \& Leslie P. Francis, Debilitating Alexander v. Choate: 'Meaningful Access' to Health Care for People with Disabilities, Fordham Urban Law Journal 35: 447-477 (2008). 
otherwise qualified individuals cannot enjoy opportunities on a par with how others enjoy them. Most importantly, meaningful access means changing accepted rules or structures that in practice make it difficult for people disfavored by them because of their disabilities from enjoying opportunities for which they are otherwise qualified. Otherwise neutral rules are put to the test of whether changes in them would be a fundamental alteration of the activity or impose people to direct threats when activities are restructured. More specifically, meaningful access is violated if individuals with disabilities are relegated to dependence on others to enjoy the opportunity, as when visually impaired individuals must rely on others to tell them the denominations of paper money when a change in currency design would enable them to tell the differences for themselves via touch. ${ }^{26}$ Meaningful access is violated when individuals with disabilities have greater difficulties than others in entering facilities or must do so in ways that are demeaning, as when people with mobility impairments must be carried up steps into courtrooms. ${ }^{27}$ It is violated when people with disabilities cannot enjoy events as others can, because of how these events are communicated or presented, as when communication at sporting events is only in aural form. ${ }^{28}$ Meaningful access also is violated when individuals with disabilities do not have effective protection in exercising their rights, as when parking regulations are not enforced. ${ }^{29}$ Each of these accepted practices and many others have been changed when put to the meaningful access test. My suggestion, developed below, is that regulatory acceptance of separate men's and women's competitions might not withstand meaningful access scrutiny in some respects.

There also have been significant changes in the circumstances of college and university sports in the four decades since Title IX. One critical change is participation rates of girls in sports at the secondary school level and earlier. Another feature of the current landscape is the persistent dominance of football among sports for boys and among sports overall. The 2014-2015 rates of participation in high school athletics ${ }^{30}$ illustrate:

Total for all sports: 7,807, 045

Total for all girls sports: $3,287,732,42.1 \%$ of the total

Total for boys football: $1,083,617$, nearly $14 \%$ of the total (putting this statistic another way, the number of boys participating in high school football is one third of the number of girls participating in all sports, and just under $24 \%$ of all boys participating in high school sports)

\footnotetext{
${ }^{26}$ American Council of the Blind v. Paulson, 525 F.2d 1256 (D.C. Cir. 2008).

27 Tennessee v. Lane, 541 U.S. 509 (2004).

${ }^{28}$ Innes v. Board of Regents of the University System of Maryland, 29 F. Supp. 3d 566 (D. Md. 2014).

${ }^{29}$ E.g. Van Velzor v. City of Burleson, 43 F. Supp. 3d 746 (N.D. Texas 2014).

${ }^{30}$ From the report of the National Federation of State High School Associations, 2014-2015 High School Athletics Participation Survey, http://www.nfhs.org/ParticipationStatics/PDF/201415_Participation_Survey_Results.pdf, calculations by the author.
} 
Percentage girls to boys in sports outside of football: $54.7 \%$

Some comparisons where boys(B) and girls(G) play the same or an equivalent sport:

Baseball/softball: 486,567 B; 364,103 G

Basketball: 541,479 B; 429,504 G

Cross country: 250,981 B; 221,616 G

Swimming \& diving: 137,087 B; 166,838 G

Soccer: $432,569 \mathrm{~B} ; 375,681 \mathrm{G}$

Tennis: $157,240 \mathrm{~B} ; 182,876 \mathrm{G}$

Track \& Field: 578,632 B; 478,176 G

These data compare with the approximately 3.67 million boys and only 300,000 girls playing competitive high school sports at the time Title IX was adopted. ${ }^{31}$ Clearly, girls at the secondary school level are participating robustly in sports and doing so at levels roughly equivalent to those of boys-at least, if football is set aside. Club sports for girls have increased as well; for example, the Olympic Development Program for youth soccer in the US began in 1977 and the formal program for girls was added in 1982.32 The rules of women's basketball were changed in 1970 to allow women to play the full-court game and the AAU began national tournaments for pre-college girls in 1972, the year of Title IX. ${ }^{33}$ There is thus a pipeline of interested and capable women today that is far more extensive than there was when Title IX began.

Extensive changes have taken place in intercollegiate athletics as well. In addition to the growth of women's sports, football has become increasingly differentiated. The National Collegiate Athletic Association was reorganized in 1973, the year after Title IX, and member schools divided into three divisions. ${ }^{34}$ Division I split into two divisions, I-A and I-AA in 1978, ${ }^{35}$ with Division I-A having access to the higherprofile bowl games. The Bowl Championship Series began in 1998 and is described as having "transformed college football into a true national treasure; with popularity, attendance, and fan viewership at record levels." 36 The BCS was

\footnotetext{
31 McCormick v. School District of Mamaroneck, 370 F.2d 275, 286 (2004).

32 US Youth Soccer, Olympic Development Program, http://www.usyouthsoccer.org/programs/olympicdevelopmentprogram/. 33 (about) education, History of Women's Basketball in America, http://womenshistory.about.com/od/basketball/a/timeline.htm.

${ }^{34}$ NCAA, Divisional Differences and the History of Multidivision Classification, http://www.ncaa.org/about/who-we-are/membership/divisional-differences-andhistory-multidivision-classification.

35 Football Geography.com, History of FBS (I-A) vs. NCAA Division II/III \& NAIA, http://www.footballgeography.com/history-of-fbs-i-a-vs-ncaa-division-iiiii-naia/ ${ }^{36}$ ESPN, The Bowl Championship Series: A Golden Era, http://www.bcsfootball.org/news/story?id=10172026
} 
supplanted in 2015 with a full college playoff system. ${ }^{37}$ In response to these developments, super-conferences have been formed made up of universities that wish to compete in football at the highest level. The television contracts for these super-conferences are major revenue producers for the schools involved in them, driving the times at which games are played and even some matchups. ${ }^{38}$ Indeed, it is fair to say that football has become a sport apart, providing entertainment for the nation, communities and alumnae; player development for the National Football League; and substantial revenue for the most fortunate schools. If entertainment was a primary purpose of college football twenty-five years ago, it is even more so today.

Men's basketball has also changed. Albeit lucrative, basketball has at some schools increasingly become less a college sport and more a source of national entertainment and player development. Male players at the highest level of basketball talent frequently spend one or at most two years at their institutions of higher education, with deleterious consequences for the sport as a collegiate affair. ${ }^{39}$ "March Madness" - the NCAA men's basketball tournament-has become a national institution earning the NCAA over $\$ 900$ million $^{40}$ and "bracketology" a household word. ${ }^{41}$

37 College Football Playoff, Chronology, http://www.collegefootballplayoff.com/chronology, 38 The Pac-12 deal, beginning in 2012 and running for 10 years, is worth $\$ 225$ million/year for the conference, ESPN, Pac-10 announces ESPN/Fox deal, http://sports.espn.go.com/ncf/news/story?id=6471380. The Big-10 has adopted scheduling rules designed to increase TV revenues, SBNation Big Ten's 3 new scheduling rules are as much about TV money as about the Playoffs, http://www.sbnation.com/college-football/2015/8/3/9086867/big-ten-footballschedule-rules-espn.

39 Blair Kerkhoff, NCAA President Mark Emmert wants end to one-and-done basketball players, Kansas City Star [online], April 23, 2015, http://www.kansascity.com/sports/spt-columns-blogs/blairkerkhoff/article19334964.html; NY Daily News [online], Duke's NCAA title, Kentucky's near-perfect season prove one-and-done the new normal in college hoops, April 7, 2015, http://www.nydailynews.com/sports/college/rubin-one-anddone-new-normal-college-hoops-article-1.2177034; John Feinstein, College basketball's one-and-done rule must be done with immediately, Washington Post [online], January 31, 2015, https://www.washingtonpost.com/sports/colleges/college-basketballs-one-anddone-rule-must-be-done-with-immediately/2015/01/31/e465091e-a8e1-11e4a2b2-776095f393b2_story.html.

40 Jonathan Berr, March Madness: Follow the money, CBS News March 20, 2015, http://www.cbsnews.com/news/march-madness-follow-the-money/.

41 E.g. The Bracket Project, Ranking the Braketologists, http://bracketmatrix.com/rankings.html. 
While women's sports, basketball, and football have burgeoned, other men's sports have languished by comparison. Sports such as gymnastics or wrestling have been particularly hard hit by cancellations at many schools. ${ }^{42}$ Universities have not introduced men's varsity teams in sports such as soccer that have grown in popularity recently out of Title IX concerns. Although Title IX is frequently blamed for the conditions of non-football men's sports, NCAA scholarship rules have tracked revenue rather than high school participation rates in many sports and have played a role as well. ${ }^{43}$

In sum, over the time since Title IX took effect, college and university sports have taken on highly differentiated roles. The entertainment role of some sports, especially men's football and basketball, has mushroomed. Other sports, both men's and women's may not provide fully meaningful access for students who wish to participate in them, at least in part due to NCAA rules and Title IX regulations that may not have kept pace with current realities-or with current understandings of equal opportunity.

\section{IV: Two Modest Proposals for Increasing Meaningful Access by Men and Women in College Athletics.}

This section sketches and defends two possible improvements of the current situation in college athletics. It accepts what has happened to football and basketball—whether or not these developments are regarded as just-and considers what might be improvements overall in the opportunities provided by varsity athletics. These improvements are: (1) recognize that college football is a distortion, and should be set aside in considering what equality requires; (2) reconsider segregation of men's and women's sports, not by including women on men's teams or men on women's teams, but by restructuring some sports to involve competitions by both sexes.

Setting football aside. Football is the only significant college sport played by men only without a corresponding similar women's sport. Football is also a huge consumer of numbers-with 85 scholarships allowed for the highest division in $2014 .{ }^{44}$ On any straight numbers test for equality, football dwarfs all other sports. Title IX and subsequent regulations failed to take the implications of this distortion sufficiently into account.

\footnotetext{
${ }^{42}$ Karen Owoc, Title IX and Its Effect on Men's Collegiate Athletics, http://usasports.org/TitleIX.pdf.

43 Peter Keating, The Silent Enemy of Men's Sports, ESPNW [online], http://www.kansascity.com/sports/spt-columns-blogs/blairkerkhoff/article19334964.html (May 23, 2012).

${ }^{44}$ Scholarship Stats.com, College Football \& Scholarship Opportunities, http://www.scholarshipstats.com/football.html.
} 
When Title IX was enacted, opponents such as Senator John Tower from Texas sought to introduce amendments to exempt all revenue-producing sports from its reach..$^{45}$ At the time, only men's sports were revenue producing, and the effort was a thinly veiled attempt to undermine Title IX's implications for collegiate athletics more generally. The result of the Tower amendment was direction by Congress to the then-department of Health, Education, and Welfare to adopt regulations crafted to take into account the differences among sports. ${ }^{46}$ The result was the regulations distinguishing equality by the numbers-applying to numbers of participants and scholarships-equality by similarity of equipment, and overall equality of opportunity in athletics programs. The agency's reasoning for adopting the rule in the form that it did does not indicate consideration of football as a separate case; rather, it replies to comments by the NCAA and others reiterating the Tower amendment's proposal to exempt all revenue-producing sports from Title IX.47

The changes in circumstances since Title IX was enacted detailed in the preceding section at least suggest that it might be time to reconsider the regulations' application to football. Title IX has become entrenched in the collegiate landscape and it seems unlikely that reconsideration of the role of football would dislodge it. For better or for worse, football plays a unique role in college sports today, one that distorts Title IX's application to other sports and continuing resentment of its supposed effects. Given the data about secondary school participation, moreover, a more accurate reflection of meaningful access would consider opportunities for both women and men outside of football. Application of the same number standard to numbers of athletes and scholarships in all sports including football is arguably in tension with consideration of whether the test of full and effective accommodation for all sports is met.

Considering combining men's and women's competitions. A continuing concern of many female athletes is that their sports receive less attention than their male counterparts, in respect, publicity, and attendance, among other factors. Continued existence in the shadows, women contend, means that they are not afforded meaningful access to the benefits of athletic participation that are available to men. The Title IX regulations accept the separation of men's and women's competitions, largely because of difficulties posed when men and women compete against one another. But acceptance of this separation might be subject to the kind of scrutiny given requests for disability accommodations when qualified individuals challenge workplace policies as exclusionary: refusal to change rules in ways to allow capable individuals to perform essential job functions or experience public services or

45 Women's Sports Foundation, Title IX Legislative Chronology, http://www.womenssportsfoundation.org/home/advocate/title-ix-andissues/history-of-title-ix/history-of-title-ix.

${ }^{46}$ Women's Sports Foundation, Title IX Legislative Chronology, http://www.womenssportsfoundation.org/home/advocate/title-ix-andissues/history-of-title-ix/history-of-title-ix. ${ }^{47}$ Fed. Reg. 40(108) at 24134 (June 4, 1975). 
accommodations are reasonable unless they would be undue hardships (for employment) or fundamental alterations (for public services or accommodations) or pose direct threats to the individual or others.

Other than permitting women to participate on men's teams, or women to compete against men, there are several possible ways to restructure sports to increase inclusion and the opportunities it brings. Consider sports involving individual competition such as tennis, golf, swimming and diving, skiing, track and field, sculling, or gymnastics. It is possible to structure meets that include both male and female competitions in the same sport but with women competing against women, and men against men. Counts that determine overall winners could include both female and male competitive events: for example, tennis teams could be made up of both men and women, with the men competing against the men and the women against the women, counting both the finishing places of women and the finishing places of men in determining overall results. Or, a gymnastics meet could include both male and female events. This parallels the compilation of national medal counts in competitions such as the Olympics or the rating of university athletics programs' success overall. There are advantages to such a structure, including potentially reduced travel costs as male and female athletes could travel together as members of the same team to events. Such structures might also yield economies of scale for publicity, ticket sales, coaching and training, or cheering and other forms of support. Not inconsequentially, it also might cast light on continued discrepancies between resources provided to male and female teams in the same sport, such as coaching, training, or volunteer assistants.

There are also sports that involve mixed competition. Mixed doubles in tennis is an example, as are mixed double sculls in rowing. ${ }^{48}$ With segregation between male and female teams, such sports are not available at the university level-despite their potential popularity among athletes. Sports such as ultimate Frisbee have developed with mixed divisions that could be developed for intercollegiate competition at both the club and varsity levels. It is short sighted indeed to ignore forms of inclusion such as these that could potentially be more reflective of meaningful sports opportunities than the current segregation by sex of sports at the college and university level.

\section{Conclusion}

Title IX was an important first step towards inclusion of women at all levels of sports. In many ways, it has been a remarkable success. But in others, it has not, for both men and women. Title IX regulations have remained frozen in time, failing to account for important developments in theorizing about equality and in sports

${ }^{48}$ Mixed double sculls is featured in the Paralympics; the US won its first medal in the sport in 2012. Allison Fredrick, US wins firs ever medal in mix doubles sculls, http://www.teamusa.org/US-Paralympics/Features/2012/September/02/USmixed-doubles-wins-bronze. 
themselves. Reconsideration of the structure of college and university athletics programs in light of these developments is overdue. 